\title{
4 poemas
}

Carla Diacov ${ }^{1}$

graças a deus entre nós

dar nome ao prato

com o resto da tarde

espinha de peixe e

mosca inteira

dar nome

porque devemos chamá-lo

porque estava era um

de nós à mesa

e nele o resto de tudo que não

foi digerido

dar nome pois

que nomeado terá chances

de ser magoado culpado trincado

cúmplice

um prato

desde o começo era ele entre

nós e deitamos do tudo sobre o

ódio e sobre as alamedas vazias

que em chulo dialeto

fizemos dos nossos almoços de domingo

graças a deus

graças a deus entre nós

espinha de peixe e

mosca inteira

seu apelido

\footnotetext{
1 Poeta formada em Teatro. Estreia em livro, além da participação em algumas antologias, com Amanhã Alguém Morre no Samba (Douda Correria, Portugal, 2015). Tem participação em diversas revistas on-line e impressas.
} 
efetuar pagamento

o peso desse lápis

não é o peso da certeza

em algum momento da vida

vou ser muito mais parecida com minha mãe

mais do que já sou

serei muito mais parecida com meu pai em algum outro

momento

serei muito mais parecida com uma vizinha que tive

vera me acordava com deus aos berros

serei muito parecida com o padeiro

em algum passo mais largo que esse

em algum espirro mais breve

serei parecida com a megera flor que vejo no vaso

com a água cheia de larvas

em algum momento da trilha serei

mais aquela que quero ser hoje

uma que não precisa se alimentar

uma que não usa roupas

uma que não desperdiça os olhos

os ovos os ombros os vasos

o peso desse lápis não é mesmo o peso da certeza

minha mãe está fazendo chá de alguma coisa

meu pai está em algum lugar escondido de tudo

em todo momento

meu pai está

em algum memento meu pai será

muito mais parecido comigo

e já o peso do lápis confere o documento que segue

meu pai então

protocolado 
Ihufas vão bem com vinho turvo

alguém diz que o dia é baldio

basta a vibração das palavras para

que um homenzinho

alimente o gato

corte os cabelos

acarinhe o pensamento sujo

de pássaros

basta a vibração

para

que o chão esteja

para que o chão receba o rosto e os joelhos

do corpo que cai com a visão

mandalas na radiação solar

basta o sol embutido nalgum sentido

do dia baldio para que

alguém comece a salgar a carne

lavar as folhas

alguém diz que o dia é baldio

alguém diz lhufas vão bem com vinho turvo

alguém com alguém passa 11 horas num

elevador entre o sexto e o sétimo piso

fazem um filho ou uma saída

o dia é baldio

alguém cai duro no sofá de bambu

alguém espera que o dia baldio acabe

então basta

esperar para que a noite chegue

inculta

cabendo a tudo

o dia na noite com salada

sujeira de pássaros

Ihufas um filho uma saída 


\section{lá em vem a cólera em busto e fogo}

.para a série "enterradas vivas" da revista Modo de Usar \& CO.

canta mãe olha

a cólera e a cólera jovita

olha cá como o mato seco

lembra a pequena mania antônia veja só

vermelho que dá em tudo jovita olha

chumbo que dá nos dentes há hepáticas secas

do tempo que se conta há índios

negros do front

dum couro leve suave mãe

nada me vale para sempre

nada sensação para além do imperioso

guilherme olha antônia guilherme

desde agora

mãe

são nomes e cólera e couro suave eusébio

guilherme toma olha aqui

é de punhal é de fogo é de farda a fábula que

quero contar olha mãe

de couro suave amarrava os peito

sê lenda guilherme lembra eusébio em nada

eusébio mira o nada homem

fui ter com meu pedaço de nada

um tanto do tudo mãe

há quantas crianças cresci jovita

a cólera sim tece vivendeiras

cavalo branco trotando a preto

a farda o couro a ravina olha

cavalo filetado bendito ao vinho

mata bendita olha tanto da infantaria

postiça mata olha anna

comme des enfants

elegantes elefantes da origem fabulosa 
segura anna olha o couro suave olha anna escuta os anjos desde humaitá antônia santos intrusos gritos vem e olha jovita filha índia e asa de joana francesa sonha e olha na prata o fogo Jovita e farda idolatra e cheira pinta o mapa ó pátria cuida olha suave o couro voluntários da corda acordados da pátria jovita vê joana em chamas olha o punhal guilherme queixa a ladainha quela que te fiz amasiada bacamarte sorte debaixo da lona uniforme escuta antônia joana olha jovita mãe é um couro duro suave de passar faca de afiar voz mãe é coral suave trêmula cantilena eusébio olha cá o couro comendo eusébio antônia é aceitável cólera precisa amontoada bravura em sépia conta os tons guilherme deu no jornal joana chama em chamas há tons desde eusébio cala-te caga e olha eusébio olha o couro treme suave atira homem acavala o ferro no ombro assim e desta forma atira mata o nada mira o meio ao meio nada onde pode o mapa dum tudo olha meu primeiro tiro aos 12 matei pedaços de nada toda aferro apenas e às penas para ser nome de avenida querendo a nome fronteiriço

jovita há quantas chamas ouvia joana olha escutava visões desde humaitá lá em vem a cólera em busto e fogo mãe

há tantas tranças chamava humaitá desde o chamado jornal do comércio ia o mapa jovita o mapa há tantas fábulas fogos punhal crianças anna sargento símbolo primeiro jovita o mapa nott

há quantas jovitas olha mãe quereria a honra para estrebuchar outras 